\title{
Oncolytic Viruses to Treat Ovarian Cancer Patients - a Review of Results From Clinical Trials
}

\section{Onkolytische Viren zur Behandlung von Ovarialkarzinompatientinnen - Eine Übersicht der Ergebnisse klinischer Studien}

Autoren

Institute
A. D. Hartkopf ${ }^{1}$, T. Fehm ${ }^{1}$, M. Wallwiener ${ }^{2}$, U. Lauer $^{3}$

${ }^{1}$ Department of Obstetrics and Gynecology, University of Tübingen, Tübingen

${ }^{2}$ Department of Obstetrics and Gynecology, University of Heidelberg, Heidelberg

${ }^{3}$ Department of Gastroenterology and Hepatology, University of Tübingen, Tübingen

Key words
ovarian cancer
breast
biomarker
cell culture
Schlüsselwörter
Biomarker
Mammakarzinom
Ovarmalignom
Zellkultur

eingereicht 28.11 .2011

revidiert 20.12.2011

akzeptiert 23.12.2011

\section{Bibliografie}

DOI http://dx.doi.org/

10.1055/s-0031-1298281

Geburtsh Frauenheilk 2012; 72:

132-136 @ Georg Thieme

Verlag KG Stuttgart · New York . ISSN 0016-5751

Korrespondenzadresse Dr. Andreas Daniel Hartkopf,

M. D., M. SC.

University of Tübingen

Department of Obstetrics

and Gynecology

Calwerstraße 7

72076 Tübingen

andreas.hartkopf@

med.uni-tuebingen.de

\section{Abstract \\ $\nabla$}

Oncolytic viruses are replication competent "live" viruses. They infect tumor cells, replicate highly selective inside and thereby destroy them. Because of the enormous advances in the field of genetic engineering and biotechnology during the last decade, virotherapy is increasingly used within clinical trials and proved to be safe and effective. In particular, treatment of ovarian cancer patients is one main focus of research. On the one hand, this is due to the poor prognosis of this dismal entity, resulting in the urgent need for novel therapeutics. On the other hand, as ovarian cancer typically spreads within the peritoneal cavity, intraperitoneal administration of oncolytic viruses is feasible. This paper provides an overview of promising results from clinical trials to treat ovarian cancer patients with oncolytic viruses.

\section{Introduction}

$\nabla$

Every year, around 9600 women in Germany develop ovarian cancer. This makes it the fifth most common type of cancer in women. Because of its rare symptoms, $65 \%$ of the cases are diagnosed at a very late stage (FIGO III-IV) [1]. Despite advanced surgical techniques and modern systemic therapies (chemotherapy, targeted biological therapies), the 5-year probability of survival (around 30\%) has barely improved at all over recent decades $[2,3]$. New therapeutic approaches are therefore urgently needed.

The treatment of ovarian cancers using oncolytic viruses offers a very promising approach [4]. These are "living" agents which specifically infect and kill tumour cells as part of the virus replica-

\section{Zusammenfassung \\ $\nabla$}

Onkolytische Viren sind replikationsfähige „lebende" Viren. Sie infizieren hochselektiv Tumorzellen, vermehren sich in diesen und zerstören sie dabei. Aufgrund der enormen Fortschritte auf dem Gebiet der Gen- und Biotechnologie kommt die Virotherapie zunehmend in klinischen Studien zum Einsatz und erweist sich als äußerst sicher, nebenwirkungsarm und effektiv. Insbesondere findet sich bei der Behandlung von Ovarialkarzinompatientinnen ein wichtiger Forschungsschwerpunkt. Zum einen liegt dies an der schlechten Prognose der Erkrankung und der hieraus resultierenden Notwendigkeit neuer Therapiemodalitäten. Zum anderen breitet sich das Ovarialkarzinom typischerweise lokoregionär aus, woraus sich die spezielle Möglichkeit der intraperitonealen Applikation onkolytischer Viren ergibt. Die vorliegende Arbeit fasst die vielversprechenden Ergebnisse klinischer Studien zur Behandlung von Ovarialkarzinompatientinnen mit onkolytischen Viren zuammen.

tion process. Huge numbers of progeny virions are released, which in turn attack further tumour cells. The capability of constant, tumour-specific replication is a property that sets virotherapy apart from classical gene therapy, in which viral vectors that are not able to replicate are used to insert foreign genetic material into cells. Moreover, oncolytic viruses can also be used as "gene carriers" to enhance their antineoplastic effects. In contrast to classic gene therapy, the therapeutic transgene, coupled with the viral vector from which it is coded, spreads out within the tumour. This overcomes the hitherto primary transduction inefficiency of tumour cells, a significant limitation in gene therapy for cancer [5].

The use of oncolytic viruses to treat tumours is not a new idea. Interestingly, viruses with natural 
oncolytic properties were first described at the start of the last century; a retrospective of the history of virotherapy can be found in Kelly et al. [6]. In the mid-20th century, cases of spontaneous tumour remission were reported following natural infection with measles virus $[7,8]$. Clinical trials and case studies followed in which adenoviruses or the Newcastle Disease Virus (NDV) were used, among others, to treat tumours $[9,10]$. However, the inadequate effectiveness, a lack of tumour specificity and dose-limiting side effects made it clear, that a comprehensive understanding of how oncolytic viruses work would be essential if they were to be used in clinical practice. Since the capability for the genetic characterisation and manipulation of viral vectors did not exist in those early days, virotherapy has only experienced a renaissance since the start of the rapid developments in the field of gene- and biotechnology in the 1990s. Now, both the tumour selectivity and the anti-neoplastic properties of oncolytic viruses can be specifically manipulated and optimised. As a consequence hundreds of patients are able to take part in prospective clinical virotherapy studies (including phase III), today [11].

This paper offers an overview of oncolytic viruses that are used in clinical studies to treat patients with ovarian cancer. The basic principles of virotherapy and its particular characteristics are also explained. Future challenges and the potential that oncolytic viruses offer will then be discussed.

\section{Mechanisms of Tumour Selectivity \\ $\nabla$}

Throughout evolution, viruses have excelled at specialising in penetrating host cells and appropriating their biosynthetic apparatus. Thereby, they manipulate essential cell functions such as cell division, differentiation and cell death.

These cellular changes are frequently very similar to the changes that a cell experiences during carcinogenesis (e.g. inactivation of the tumour suppressor gene $\mathrm{p} 53$, manipulation of the interferon system, stimulation of the cell cycle, suppression of apoptosis) [12]. This is one of the reasons why various viruses prefer to grow in tumour cells. Viruses with natural oncolytic properties include Newcastle Disease viruses (NDV) [13], Vaccinia viruses VV [14], vesicular stomatitis viruses (VSV) [15], parvovirus H1 (H-1PV) [16], measles vaccine viruses (MeV) [17] and reoviruses (RV) [18]. Viruses can also be genetically engineered so that they are dependent on neoplastic host cells to reproduce. This is achieved by (1) modifying the viral envelope to allow selective uptake into tumour cells, (2) disabling a gene needed for efficient replication in normal cells but which neoplastic cells can do without, and (3) creating tumour or tissue-specific promoters that regulate the expression of viral genes [12]. It is also possible to combine these approaches [19]. Table 1 provides an overview of oncolytic viruses that are already used in clinical studies to treat patients with ovarian cancer.

\section{Viruses with Natural Tumour Selectivity \\ $\nabla$}

Living viruses capable of replication have already been used millions of times in the context of vaccination and are known to be extremely safe therapeutic agents with low side effects [20]. The use of "live" vaccine viruses for oncolytic virotherapy therefore would seem to be an elegant approach. Interestingly, some vaccine strains replicate better in neoplastic cells than the corresponding wild type viruses. Measles vaccine viruses, for example, have natural oncolytic properties. In contrast to wild type measles virus they predominately enter cells via the CD46 receptor which is over-expressed by malignant cells including ovarian cancer [21,22]. An innovative approach was described by Peng et al at the Mayo Clinic in Rochester, USA: they generated a measles vaccine virus encoding for the human carcino-embryonic antigen (CEA) (MeV-CEA) [23]. During virotherapy with $\mathrm{MeV}-\mathrm{CEA}$, a simple blood test can be taken to determine the CEA level, thereby allowing viral replication to be monitored in real time. Galanis et al. recently published the results of a phase I trial on the intraperitoneal use of MeV-CEA in patients with advanced ovarian cancer [24]. The virus application was well tolerated, could easily be monitored by determining serum CEA levels and demonstrated promising clinical activity.

Another vaccine virus, the Vaccinia virus (VV), has successfully been used to treat smallpox. Numerous clinical studies have also demonstrated that VV has natural oncolytic properties [25-28]. The use of VV for oncolytic virotherapy is regarded as very safe and generally only causes mild, flu-like symptoms. Disabling two viral genes enhances tumor selectivity: thymidine kinase (TK) enables the virus to replicate independently of the host cell's cell cycle, and the Vaccinia growth factor (VGF, similar to the epidermal growth factor EGF) makes it easier for the virus to infect neighbouring cells [29]. Both TK and EGF are over-expressed by many tumour cells, which is why their deletion within the VV genome makes virus replication more difficult in non-neoplastic cells, while neoplastic cells are able to produce large volumes of progeny viruses. Pre-clinical studies using VV to treat ovarian cancer demonstrated an excellent anti-tumour activity [30]. In view of the large virus genome, $\mathrm{VV}$ is also an excellent vector for

Tab. 1 Oncolytic viruses that have been used in clinical phase 1 studies on the treatment of patients with ovarian cancer.

\begin{tabular}{|c|c|c|c|c|}
\hline Virus & Name & Mechanism of tumour selectivity & Result & Reference \\
\hline $\begin{array}{l}\text { Measles } \\
\text { vaccine } \\
\text { virus }\end{array}$ & MeV-CEA & Natural tumour selectivity & $\begin{array}{l}\text { Good tolerance. Dose-dependent stabilisation of } \\
\text { the progress of the disease in } 14 \text { out of } 21 \text { patients } \\
\text { with an average duration of } 93 \text { days. }\end{array}$ & [24] \\
\hline \multirow[t]{3}{*}{ Adenovirus } & Onyx-015 & $\begin{array}{l}\text { Deletion in the E1B and E3B gene (tumour selectivity } \\
\text { for cells with defective p53 signal transduction path- } \\
\text { way and defective RNA transport) }\end{array}$ & $\begin{array}{l}\text { Good tolerance. No clear radiological or clinical } \\
\text { tumour response. }\end{array}$ & [39] \\
\hline & $\mathrm{H} 101$ & $\begin{array}{l}\text { Deletion in the E1B and E3B gene (tumour selectivity } \\
\text { for cells with defective p53 signal transduction path- } \\
\text { way and defective RNA transport) }\end{array}$ & $\begin{array}{l}\text { Good tolerance. } 3 / 9 \text { patients with complete re- } \\
\text { mission, } 2 / 9 \text { with partial remission and } 4 / 9 \text { with } \\
\text { no tumour response. }\end{array}$ & {$[40]$} \\
\hline & $\begin{array}{l}\text { Ad5-delta24- } \\
\text { RGD }\end{array}$ & $\begin{array}{l}\text { Binds to } \alpha v \beta 3 \text { and } \alpha v \beta 5 \text { integrins; deletion in the E1A } \\
\text { gene (tumour selectivity for cells with defective reti- } \\
\text { noblastoma protein-dependent cell cycle control) }\end{array}$ & $\begin{array}{l}\text { Good tolerance. } 15 / 21 \text { patients with stable } \\
\text { disease, } 6 / 21 \text { with progressive disease and } \\
7 / 21 \text { with decreasing } C A 125 \text {. }\end{array}$ & {$[42]$} \\
\hline
\end{tabular}


additional therapeutic transgenes. Chalikonda et al. generated a VV encoding for the suicide gene cytosine deaminase (CD) (vvDD-CD). This converts the non-toxic prodrug 5-FC into cytotoxic 5-FU. In an animal model to treat ovarian cancer, the addition of the prodrug increased the oncolytic activity of vVDD-CD in a tumour-specific and highly significant manner [31].

Multiple phase I/II clinical trials using VV are currently being carried out on the treatment of ovarian cancer (http://www. jenerex.com). Currently, the first german virotherapy phase I trial to treat therapy resistant peritoneal carcinosis is initiated, which includes a large proportion of ovarian cancer patients with peritoneal recurrence (http:/www.clinicaltrials.gov/ct2/show/ NCT01443260?term=GL-ONC1\&ra=1).

One of the first virotherapy approaches for the treatment of ovarian cancer was the use of oncolytic reoviruses. These doublestranded RNA viruses replicate highly selectively in tumour cells with an activated Ras signal transduction pathway. Hirasawa et al. demonstrated in animal models that reoviruses are able to shrink ovarian cancer, reduce the formation of ascites and significantly prolong the survival of animals given this treatment [32]. Reoviruses of serotype 3 (Reolysin ${ }^{\circledR}$, Oncolytics Biotech) are currently being used in numerous clinical phase I and II trials that include to treat advanced ovarian cancer (http://www. clinicaltrials.gov/ct2/results?term=Reolysin) [33]. Following both, intraperitoneal and intravenous virus application, there was excellent tolerance, tumour-specific viral replication and oncolytic activity [34,35].

\section{Viruses with Genetically-Engineered Tumour Selectivity \\ $\nabla$}

In many cases, viral gene products require the proliferation of the host cell or inhibit anti-viral defence mechanisms. Since tumour cells proliferate actively and frequently have limited viral defences, the disabling of certain viral genes brings about artificial tumour selectivity. Consequently, the adenoviral protein E1B binds to and inactivates tumour suppressor $\mathrm{p} 53$, thereby promoting continuous viral replication [36]. Disabling E1B accordingly leads to the targeted infection of cells with defective p53 signal transduction pathway. Both adenoviruses Onyx-015 and H101 (Sunway Biotech, Shanghai, China) have corresponding deletions in the E1B gene $[37,38]$. Onyx-015 was the first genetically modified oncolytic virus to be used in clinical studies. Although the virus demonstrated promising oncolytic activities in pre-clinical studies, a phase I trial on the treatment of patients with ovarian carcinoma showed no clear clinical or radiological tumour response [39]. H101 is the first oncolytic virus to receive market approval (in China, not in western countries) based on phase III trials. A phase I trial on the treatment of malignant ascites in ovarian cancer patients led to a significant reduction in the frequency of paracentesis, which markedly improves quality of life [40].

The primary point of attack for the adenoviruses mentioned is the Coxsackie adenovirus receptor (CAR). The reason for the inadequate clinical effectiveness of Onyx-015 in the treatment of ovarian cancer may be the highly variable expression of CAR and a resulting inadequate transduction efficiency of the addressed tumour cells. Genetic modifications of the viral envelope may accordingly lead to an increased binding affinity towards ovarian cancer cells. The adenovirus Ad-delta24-RGD, for example, binds to integrins in the cell surface, including those of ovarian carcino- ma cells [41]. The adenoviral E1A protein also lacks the binding point for the cell cycle-regulating retinoblastoma $(\mathrm{Rb})$ protein. Consequently, Ad-delta24-RGD replicates selectively in cells with an inactive $\mathrm{Rb}$ signal transduction path and accordingly in many neoplastic cells, including ovarian carcinomas. In a phase I trial on the treatment of patients with gynaecological cancers, the intraperitoneal administration of Ad-delta24-RGD was well tolerated [42]. Replication of Ad-delta24-RGD in the patients' ascites and promising clinical activity was also demonstrated.

\section{Challenges and Requirements of Oncolytic Therapy $\nabla$}

Genetic stability is important both for production technology and safety-related reasons. Ultimately, it must be possible to produce the virus easily and efficiently (i.e. with a high titre). Vaccine viruses in particular (live vaccines) satisfy these requirements. In light of the many years' experience involving enormous patient numbers, there is plenty of experience available regarding safety and side effects. Technology is available for efficient virus production with high quality requirements of the production processes, which also contribute towards a high degree of genetic stability. One disadvantage of using vaccine viruses, however, is the high seroprevalence for the agent. With systemic application in particular, which appears to be the medium of choice for advanced cancer, oncolytic viruses are not only subjected to the innate immune response, but also to acquired defence mechanisms [43]. When treating ovarian cancer, the frequent loco-regional disease spread lends itself to intraperitoneal application. Although antiviral antibodies may be present in malignant ascites, a phase I study shows that the intraperitoneal use of measles vaccine viruses does not cause a rise in the antibody titre and that the tumour response does not correlate with the pre-therapeutic presence of anti-measles antibodies [24,44]. Various approaches to circumvent anti-viral immune responses have also been described. On the one hand, there are approaches which eliminate viruses by modulating the immune response, for example through the simultaneous application of immuno-suppressive substances $[45,46]$. Another approach is one taken naturally by many viruses: by infecting endogenous, circulating cells, they mask themselves from the immune system. In an analogy to this, oncolytic viruses can be administered in carrier cells and delivered to the primary tumour concealed ("Trojan Horses") [47]. This will ensure that the agent is no longer recognised by the immune system. Viral replication can also take place within the "Trojan", and the carrier cells can contribute towards the tumour selectivity by selecting cells with inherent tumour tropism [48]. The consequences of the immune response, however, do not all have a negative effect on the effectiveness of virotherapy. The interaction of the immune system with virus-infected cells appears to contribute to the oncolytic activity in vivo and in particular induce positive long-term effects by stimulating the anti-tumour immune defence. These effects can be amplified by cloning transgenic immuno-modulators into the viral genome. The problem when investigating interactions of oncolytic viruses with the immune system, however, is that immune-compromised Xenograft mice are frequently used as the tumour model. Extensive translational research in the context of clinical trials to characterize immuno-virotherapeutic effects is therefore essential and is one main interest of the German Consortium for Translational Cancer Research (DKTK), which is currently being set up. In an innovative clinical approach led by A. Hemminki (Advanced Therapy 
Access Program), patients with advanced, solid tumours that are refractive to treatment (including patients with ovarian cancer) are treated with adenoviruses that express GMCSF (Granulate Macrophage Colony Stimulating Factor) [49,50]. GMCSF stimulates the anti-tumour immune response by activating $\mathrm{CD}^{+} \mathrm{T}$ lymphocytes and natural killer cells. The treatment is tolerated well and has positive effects in the majority of the patients treated. There is also an anti-tumour as well as an anti-viral immune response. This in particular indicates that the immunological tolerance to tumour tissue can be broken through by oncolytic viruses.

\section{Summary and Outlook \\ $\nabla$}

Virotherapy is a highly promising approach to treat ovarian cancer. Several clinical trials have demonstrated the therapy's clinical effectiveness. Unlike intraperitoneally administered chemotherapy, intraperitoneal virus administration is tolerated very well [51]. The wholly different method of action compared to that of classic cytostatics means on the one hand that tumours resistant to chemotherapy could be sensitive to oncolytic viruses [52, 53]. On the other hand, the occurrence of negative side effects is not anticipated when combined treatment involving oncolytic viruses and classical forms of treatment is given. Oncolytic viruses are also of interest as a vehicle for therapeutic transgenes in relation to a whole variety of genetic therapy constructs. As well as generating oncolytic viruses that are optimised for the treatment of ovarian cancer, future studies should also analyse the ideal form of virus administration, the identification of potential therapeutic combination partners and the interaction of virotherapy with the immune system of affected patients.

\section{Conflict of Interest}

None.

\section{References}

1 Husmann G, Robert Koch-Inst., Hrsg. Krebs in Deutschland: 2005/2006; Häufigkeiten und Trends; Eine gemeinsame Veröffentlichung des Robert Koch-Instituts und der Gesellschaft der Epidemiologischen Krebsregister in Deutschland e.V. Berlin: Robert Koch-Institut; 2010

2 NIH consensus conference. Ovarian cancer. Screening, treatment, and follow-up. NIH Consensus Development Panel on Ovarian Cancer. JAMA 1995; 273: 491-497

3 Heitz F, Harter P, Zelazny J et al. Antiangiogenic approaches in ovarian cancer therapy. Geburtsh Frauenheilk 2010; 70: 791-797

4 Hartkopf AD, Fehm T, Wallwiener D et al. Oncolytic virotherapy of gynecologic malignancies. Gynecol Oncol 2011; 120: 302-310

5 Bitzer M, Lauer UM. [Oncolytic viruses for genetic therapy of gastrointestinal tumors]. Z Gastroenterol 2003; 41: 667-674

6 Kelly E, Russell SJ. History of oncolytic viruses: genesis to genetic engineering. Mol Ther 2007; 15: 651-659

7 Bluming AZ, Ziegler JL. Regression of Burkitt's lymphoma in association with measles infection. Lancet 1971; 2: 105-106

8 Zygiert Z. Hodgkin's disease: remissions after measles. Lancet 1971; 1: 593

9 Huebner RJ, Rowe WP, Schatten WE et al. Studies on the use of viruses in the treatment of carcinoma of the cervix. Cancer 1956; 9: 1211-1218

10 Cassel WA, Garrett RE. Newcastle disease virus as an antineoplastic agent. Cancer 1965; 18: 863-868

11 Liu TC, Galanis E, Kirn D. Clinical trial results with oncolytic virotherapy: a century of promise, a decade of progress. Nat Clin Pract Oncol 2007; 4: 101-117
12 Kirn D, Martuza RL, Zwiebel J. Replication-selective virotherapy for cancer: Biological principles, risk management and future directions. Nat Med 2001; 7: 781-787

13 Lorence RM, Rood PA, Kelley KW. Newcastle disease virus as an antineoplastic agent: induction of tumor necrosis factor-alpha and augmentation of its cytotoxicity. J Natl Cancer Inst 1988; 80: 1305-1312

14 Peplinski GR, Tsung AK, Casey MJ et al. In vivo murine tumor gene delivery and expression by systemic recombinant vaccinia virus encoding interleukin-1beta. Cancer J Sci Am 1996; 2: 21-27

15 Stojdl DF, Lichty B, Knowles $S$ et al. Exploiting tumor-specific defects in the interferon pathway with a previously unknown oncolytic virus. Nat Med 2000; 6: 821-825

16 Geletneky K, Hartkopf AD, Krempien R et al. Improved killing of human high-grade glioma cells by combining ionizing radiation with oncolytic parvovirus H-1 infection. J Biomed Biotechnol 2010; 2010: 350748

17 Zimmermann M, Armeanu S, Smirnow I et al. Human precision-cut liver tumor slices as a tumor patient-individual predictive test system for oncolytic measles vaccine viruses. Int J Oncol 2009; 34: 1247-1256

18 Coffey MC, Strong JE, Forsyth PA et al. Reovirus therapy of tumors with activated Ras pathway. Science 1998; 282: 1332-1334

19 Bauerschmitz G, Breidenbach M, Dall P et al. Mehrfach modifizierte onkolytische Adenoviren in der präklinischen Testung an Ovarialkarzinomzellen. Geburtsh Frauenheilk 2007; 67: 1102-1108

20 Cutts FT, Markowitz LE. Successes and failures in measles control. J Infect Dis 1994; 170 (Suppl. 1): S32-S41

21 Dorig RE, Marcil A, Chopra A et al. The human CD46 molecule is a receptor for measles virus (Edmonston strain). Cell 1993; 75: 295-305

22 Anderson BD, Nakamura T, Russell SJ et al. High CD46 receptor density determines preferential killing of tumor cells by oncolytic measles virus. Cancer Res 2004; 64: 4919-4926

23 Peng KW, Facteau S, Wegman Tet al. Non-invasive in vivo monitoring of trackable viruses expressing soluble marker peptides. Nat Med 2002. 8: 527-531

24 Galanis E, Hartmann LC, Cliby WA et al. Phase I trial of intraperitoneal administration of an oncolytic measles virus strain engineered to express carcinoembryonic antigen for recurrent ovarian cancer. Cancer Res 2010; 70: 875-882

25 Milton GW, Brown MM. The limited role of attenuated smallpox virus in the management of advanced malignant melanoma. Aust N Z J Surg 1966; 35: 286-290

26 Hunter-Craig I, Newton KA, Westbury G et al. Use of vaccinia virus in the treatment of metastatic malignant melanoma. Br Med J 1970; 2: 512515

27 Arakawa Jr. S, Hamami G, Umezu Ket al. Clinical trial of attenuated vaccinia virus AS strain in the treatment of advanced adenocarcinoma. Report on two cases. J Cancer Res Clin Oncol 1987; 113: 95-98

28 Gomella LG, Mastrangelo MJ, McCue PA et al. Phase i study of intravesical vaccinia virus as a vector for gene therapy of bladder cancer. J Urol 2001; 166: 1291-1295

29 McCart JA, Ward JM, Lee J et al. Systemic cancer therapy with a tumorselective vaccinia virus mutant lacking thymidine kinase and vaccinia growth factor genes. Cancer Res 2001; 61: 8751-8757

30 Hung CF, Tsai YC, He L et al. Vaccinia virus preferentially infects and controls human and murine ovarian tumors in mice. Gene Ther 2007; 14: 20-29

31 Chalikonda S, Kivlen MH, O'Malley ME et al. Oncolytic virotherapy for ovarian carcinomatosis using a replication-selective vaccinia virus armed with a yeast cytosine deaminase gene. Cancer Gene Ther 2008; 15: $115-125$

32 Hirasawa K, Nishikawa SG, Norman KL et al. Oncolytic reovirus against ovarian and colon cancer. Cancer Res 2002; 62: 1696-1701

33 Lal R, Harris D, Postel-Vinay S et al. Reovirus: Rationale and clinical trial update. Curr Opin Mol Ther 2009; 11: 532-539

34 Cohn DE, Nuovo G, Coffey MC et al. Phase I/II trial of reovirus serotype 3-Dearing strain in patients with recurrent ovarian cancer. J Clin Oncol 2010; 28: 15 s (Abstr. TP253)

35 Phelps MA, Cohn DE, O'Malley DM et al. Reovirus replication in ovarian and peritoneal tumors after intravenous administration. Proceedings of the 101st Annual Meeting of the American Association for Cancer Research 2010; Abstract No. 2594

36 Vollmer CM, Ribas A, Butterfield LH et al. p53 selective and nonselective replication of an E1B-deleted adenovirus in hepatocellular carcinoma. Cancer Res 1999; 59: 4369-4374 
37 Bischoff JR, Kirn DH, Williams A et al. An adenovirus mutant that replicates selectively in p53-deficient human tumor cells. Science 1996; 274: 373-376

38 Yuan ZY, Zhang L, Li S et al. [Safety of an E1B deleted adenovirus administered intratumorally to patients with cancer]. Ai Zheng 2003; 22: 310-313

39 Vasey PA, Shulman LN, Campos $S$ et al. Phase I trial of intraperitoneal injection of the E1B-55-kd-gene-deleted adenovirus ONYX-015 (dl1520) given on days 1 through 5 every 3 weeks in patients with recurrent/refractory epithelial ovarian cancer. J Clin Oncol 2002; 20: 1562-1569

$40 \mathrm{Liu}$ HL, Chen J. Oncolytic virus as an agent for the treatment of malignant ascites. Cancer Biother Radiopharm 2009; 24: 99-102

41 Bauerschmitz GJ, Lam JT, Kanerva A et al. Treatment of ovarian cancer with a tropism modified oncolytic adenovirus. Cancer Res 2002; 62: 1266-1270

42 Kimball KJ, Preuss MA, Barnes MN et al. A phase I study of a tropismmodified conditionally replicative adenovirus for recurrent malignant gynecologic diseases. Clin Cancer Res 2010; 16: 5277-5287

43 Fisher K. Striking out at disseminated metastases: the systemic delivery of oncolytic viruses. Curr Opin Mol Ther 2006; 8: 301-313

44 Hemminki A, Belousova N, Zinn KR et al. An adenovirus with enhanced infectivity mediates molecular chemotherapy of ovarian cancer cells and allows imaging of gene expression. Mol Ther 2001; 4: 223-231

45 Lolkema MP, Arkenau HT, Harrington Ket al. A phase I study of the combination of intravenous reovirus type 3 Dearing and gemcitabine in patients with advanced cancer. Clin Cancer Res 2011; 17: 581-588
46 Fulci G, Breymann L, Gianni D et al. Cyclophosphamide enhances glioma virotherapy by inhibiting innate immune responses. Proc Natl Acad Sci USA 2006; 103: 12873-12878

47 Mader EK, Maeyama Y, Lin Y et al. Mesenchymal stem cell carriers protect oncolytic measles viruses from antibody neutralization in an orthotopic ovarian cancer therapy model. Clin Cancer Res 2009; 15: 7246-7255

48 Willmon C, Harrington K, Kottke T et al. Cell carriers for oncolytic viruses: Fed Ex for cancer therapy. Mol Ther 2009; 17: 1667-1676

49 Cerullo V, Pesonen S, Diaconu I et al. Oncolytic adenovirus coding for granulocyte macrophage colony-stimulating factor induces antitumoral immunity in cancer patients. Cancer Res 2010; 70: 4297-4309

50 Koski A, Kangasniemi L, Escutenaire $S$ et al. Treatment of cancer patients with a serotype 5/3 chimeric oncolytic adenovirus expressing GMCSF. Mol Ther 2010; 18: 1874-1884

$51 \mathrm{du}$ Bois A, Schmalfeldt B, Meier W et al. Onkologie. Ovarialkarzinom - Ist die intraperitoneale Therapie wirklich neuer Standard? Geburtsh Frauenheilk 2006; 66: 604-605

52 Lage H. Mechanismen der Chemotherapieresistenz beim Ovarialkarzinom. Geburtsh Frauenheilk 2007; 67: 831-836

53 Hartkopf $A D$, Fehm T, Wallwiener $D$ et al. Oncolytic virotherapy of breast cancer. Gynecol Oncol 2011; 123: 164-171

Deutschsprachige Zusatzinformationen mit deutschem Text online abrufbar unter: www.thieme-connect.de/ejournals/toc/gebfra. 